\title{
New records and redescriptions of American species of Mesocyclops and of Diacyclops bernardi (Petkovski, 1986) (Copepoda: Cyclopoida)
}

\author{
Janet W. Reid \\ Department of Invertebrate Zoology, NHB-163, National Museum of Natural History, Smithsonian \\ Institution, Washington, DC 20560, U.S.A.
}

Keywords: Taxonomy, Copepoda, Cyclopoida, Mesocyclops, new records, U.S.A.

\begin{abstract}
Recent collections in the south central U.S.A. have included three neotropical and one probably introduced species that are presently assigned to the cyclopoid copepod genus Mesocyclops. Mesocyclops longisetus var. curvatus Dussart, 1987, is reported from Louisiana, U.S.A., and Panama; published records of Mesocyclops longisetus (Thiébaud, 1914) sensu lato in the southern U.S.A. are reviewed. Mesocyclops reidae Petkovski, 1986, is reported from Mississippi, U.S.A., and Honduras. Mesocyclops ruttneri Kiefer, 1981, is redescribed from type specimens collected in Austria, and newly reported from Louisiana, Mississippi, China, Thailand, and Viet Nam. This species is considered to have been introduced from Asia into Austria and the U.S.A. Mesocyclops bernardi Petkovski, 1986, newly recorded from Louisiana and Mexico, is transferred to the genus Diacyclops.
\end{abstract}

\section{Résumé}

Dans des prélèvements récemment réalisés au sud des parties centrales des U.S.A. ont été découvertes trois espèces néotropicales et une espèce probablement introduite de Copépodes Cyclopoïdes actuellement considérés comme appartenant au genre Mesocyclops. Mesocyclops longisetus var. curvatus Dussart, 1987, est mentionné de Louisiane (U.S.A.) et de Panamá; sont passés en revue les mentions publiées de Mesocyclops longisetus (Thiébaud, 1914) sensu lato dans les zones méridionales des U.S.A. Mesocyclops reidae Petkovski, 1986, est connu du Mississippi (U.S.A.) et du Honduras. Mesocyclops ruttneri Kiefer, 1981, est redécrit sur des exemplaires-type d'Autriche, et nouvellement mentionné de Louisiane, du Mississippi, de Chine, Thailande, et Viet Nam; on considère cette espèce comme ayant été introduite d'Asie en Autriche et aux U.S.A. Mesocyclops bernardi Petkovski, 1986 - nouvellement mentionné pour la Louisiane et le Mexique - est transféré au genre Diacyclops.

\section{Introduction}

Taxonomic understanding of the tropico-temperate cyclopoid copepod genus Mesocyclops has greatly improved during the past decade. Recognition of the importance of formerly ignored subtle morphological, usually meristic characters by Kiefer (1981), Van de Velde (1984a, b), and Dussart \& Fernando (1988) has led to more accurate characterization of many paleotropical species. It is desirable to supply similarly detailed descriptions for the American species.

New records of copepods from non-lacustrine wetlands in the southern U.S.A. have extended the known geographical ranges of many species. Neotropical species appear to comprise a significant and previously little appreciated component of the regional copepod fauna (Reid, 1992). Several neotropical species appeared in collections of cyclopoid copepods that were made from Louisiana and Mississippi, U.S.A. by Gerald G. Marten and sent to me for determination (Marten, 1989; 1990a, b). In addition to the common North American Mesocyclops edax (S.A. Forbes, 1891), there were four species that are presently assigned to the same genus: Mesocyclops bernardi Petkovski, 1986, Mesocyclops longisetus var. curvatus Dussart, 1987, Mesocyclops reidae Petkovski, 1986, and Mesocyclops ruttneri Kiefer, 1981. Examination of material in the C.D. Marsh Collection of Copepoda in the National Museum of Natural History led to new records of $M$. longisetus var. curvatus and $M$. reidae from Panama and Honduras, respectively. The 
present article describes aspects of the morphology and reviews the known distribution of $M$. longisetus var. curvatus, $M$. reidae, and $M$. ruttneri. The transfer of $M$. bernardi to the genus Diacyclops is proposed. An additional new record for $D$. bernardi is given from Mexico.

For taxonomic examination, specimens were treated according to the methods of Reid et al. (1989). Terminology, particularly for the seminal receptacle and the antennule is taken from Fiers \& Van de Velde (1984) and Van de Velde (1984a, b). Descriptions of the morphology of species of Mesocyclops are based on the redescription of the genotype, $M$. leuckarti (Claus, 1857) by Van de Velde (1984a). Specimens are deposited either in the collections of G.G. Marten, New Orleans Mosquito Control Board, or in the U.S. National Museum of Natural History, Smithsonian Institution (USNM).

\section{Taxonomic section}

Family Cyclopidae Burmeister, 1834

Subfamily Cyclopinae Dana, 1853, char. emend. Kiefer, 1927

Genus Mesocyclops G.O. Sars, 1914

Mesocyclops longisetus var. curvatus Dussart, 1987

Synonymy. - Mesocyclops longisetus var. curvatus Dussart, 1987: 150, 156, figs. 3, 4, 7, 8; Reid, 1990: 181, table I.

Mesocyclops longisetus (Thiébaud, 1914); Marten, 1989: 232, 233, 235, table 1; 1990b: 681-687, tables 1, 4, 5, 7, 8; Reddell, 1965: 157; ?Reddell \& Mitchell, 1969: 7; ?Dussart \& Fernando, 1986: 291, 292.

Cyclops simplex Poggenpol, 1874; ?Herrick, 1887: 14, 17-18, pl. VII fig. 1.

Material. - USNM 252008, 6 ९ ९, samples M1 and M6, Lake Catherine marshes, 24 July 1991, after introduction from cultures originally collected from Joe Brown Lagoon, New

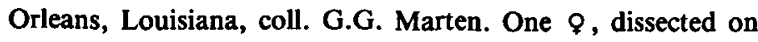
slide, and $2 \& \&$, ethanol-preserved, sample 105, New Orleans, Louisiana, 1988, G.G. Marten collection. USNM Accession No. 120079 (Marsh Collection), several $९$ on slides, Panama, C.D. Marsh prep. nos. 3826, 3827, 3842, 3843, and 3943. Unmounted specimens preserved in $70 \%$ ethanol.
Discussion. - The New Orleans specimens are congruent in the proportions of the caudal rami, the form of the antennular membrane, and in the leg 4 endopodite 3, with $M$. longisetus var. curvatus Dussart, 1987. The lateral arms of the seminal receptacles of most specimens examined are strongly recurved posteriorly. In a few specimens, these arms are little recurved posteriorly, therefore closer to $M$. longisetus (Thiébaud, 1914) sensu restricto Dussart, 1987.

The record from New Orleans was previously reported by Marten (1989, 1990b). The earliest record of $M$. longisetus sensu lato in the U.S.A. may be that of Herrick (1887), whose extensive figures of "Cyclops simplex" from southern Alabama clearly show a species of Mesocyclops with the caudal ramus haired on the medial surface, the antennular hyaline membrane with a single deep notch, and the leg 4 coupler with two triangular projections. However, the illustration of the seminal receptacle (Herrick, 1887: plate VII, fig. 1a) shows the median third of the anterior margin concave and the lateral arms tapering, not rounded as the receptacle of $M$. longisetus. Reddell (1965, repeated in Reddell \& Mitchell, 1969) reported $M$. longisetus from Felton Cave, Sutton County, Texas. The species was also recorded from Florida by Dussart \& Fernando (1986), but additional locality data for their record are unavailable (C.H. Fernando, in litt., 1990). It seems that $M$. longisetus sensu lato, which is distributed through Mexico and Central and South America as far south as Patagonia and possibly Tierra del Fuego, occurs widely although sporadically in the southern U.S.A. The distribution of $M$. longisetus var. curvatus is uncertain.

The records for Panama from the Marsh Collection are previously unpublished.

\section{Mesocyclops reidae Petkovski, 1986}

(Figs. 1, 2)

Synonymy. - Mesocyclops reidae Petkovski, 1986: 47, 61-66, 71-73, 78, Abb. 11-22; 1988: 40; Sket, 1988: 79, table 1; Reid, 1990: 181, table I.

Mesocyclops ellipticus (non Kiefer, 1936a); Yeatman, 1977: 5-7, figs. 1-16; Smith \& Fernando, 1978: 2015, 2016, 2019, 


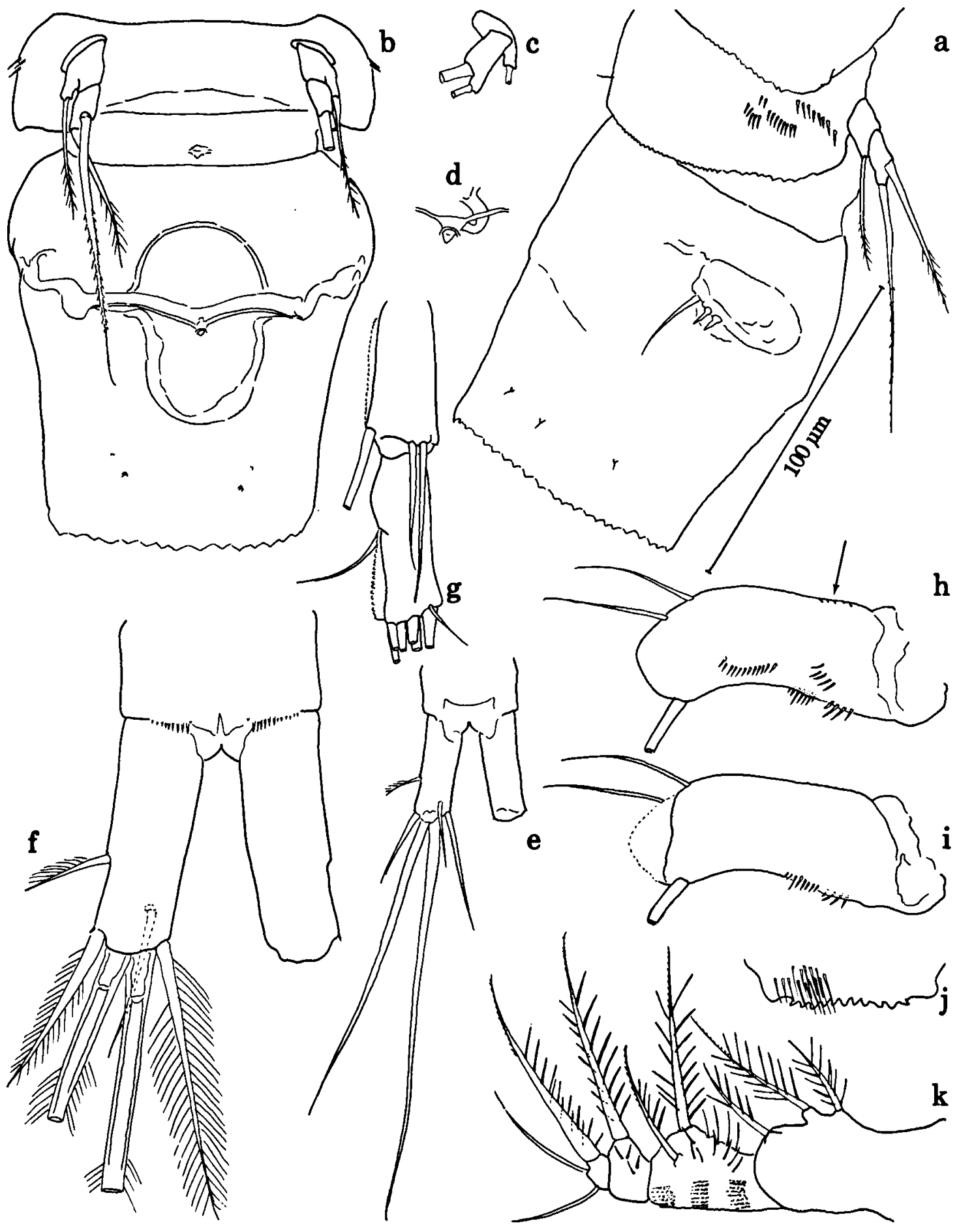

Fig. 1. Mesocyclops reidae Petkovski, 1986, dissected $\$$ from Mississippi, USNM 252009: a, pediger 5 and genital segment, right lateral; b, pediger 5 and genital segment, ventral; c, left leg 5 , lateral-oblique, setae not completely indicated; d, copulatory pore and pore-canal, lateral-oblique; e, anal somite and caudal rami, dorsal; $f$, anal somite and caudal rami, ventral; $g$, antennule articles 16 and 17 ; $h$, antenna article 1 , caudal side; $i$, antenna article 1 , frontal side; $j$, labrum, spines indicated only on one side; $k$, maxilliped. Scale applies to Figs. 1a-c only. 
2020, figs. 21-24, tables 1, 2; 1980: 11, 18, 20, fig. 9A-D, table 2; Reddell, 1981: 81; Pesce, 1985: 296, 311, 316-318, figs. 63-65.

Material. - USNM 252009, 1 \&, dissected on slide, and $10 \%$, ricefield, Cleveland, Mississippi, September 1991, coll. G.G. Marten. USNM Accession No. 120079 (Marsh Collection), 2 $\odot \odot$ on slides, C.D. Marsh prep. nos. 4288, 4296, Honduras.

Description of female. - Range of lengths of Mississippi specimens $0.80-1.02 \mathrm{~mm}$ (median $=0.90$ $\mathrm{mm}, \boldsymbol{n}=10$ ). Resembling description of Petkovski (1986) of type population from San Andrés Island, Colombia, in most details.

Supplementary observations: Posterolateral margin of pediger 4 finely serrate (Fig. 1a). Pediger 5 (Figs. 1a, b) with small lateral spines disposed in 3 diagonal rows. Leg 5 (Figs. 1a-c) with median spine inserted at distal $3 / 4$ of article 2 . Genital segment (Figs. 1a, b) lacking ornamentation except few papillae bearing sensilla near posterior margin. Pore-canal of seminal receptacle (Figs. 1b, d) short, directed dorsally, in semilateral view seen to be recurved anteriorly. Copulatory pore with slightly sclerotized anterior margin. Anal somite (Figs. 1e, f), posterodorsal margin lacking spines; posteroventral margin with small spines, mediad spines larger. Caudal ramus (Figs. 1e, f) similar to description of Petkovski (1986: 62, Abb. 13) in lacking spines near base of lateral seta, but having 2 tiny spines anterior to base of lateralmost terminal caudal seta in both Mississippi and Honduras specimens. Medialmost terminal caudal seta less than twice length of lateralmost terminal caudal seta.

Antennule article 1, small spines disposed in row as in $M$. leuckarti; articles 2-17 lacking surface spines; appendages of antennule exactly as in M. leuckarti (Van de Velde, 1984a: 14, fig. 5A). Antennule hyaline membranes (Fig. 1g), membrane of article 16 narrow, margin finely serrate rather than entire as observed by Petkovski (1986: 62, Abb. 14); membrane of article 17 broader, slightly more coarsely serrate, extending distally from seta near midlength of article.

Antenna (Figs. 1h, i) with basic spine pattern for genus, spine rows, especially row on anterior margin (indicated by arrow) short, no other surface ornamentation.

Labrum (Fig. 1j) with 2 rows of long spines on each side of median line. Maxillule as in M. leuckarti, i.e. lacking spines on surface of palp. Maxilla as in $M$. leuckarti, lacking spines on surface of coxa (article 2), distal half of ventral surface of coxa rugose. Maxilliped (Fig. 1k) article 2 (basis) with 3 transverse rows of small spines along posterior border; middle seta of article 4 (endopodite 2) short in comparison to corresponding seta of congeners.

Legs $1-4$ as in $M$. leuckarti except in following details. Leg 1 (Fig. 2a) with medial seta of basipodite short, stout, with spines at base; coupler with 2 rounded marginal expansions. Leg 2 (Fig. 2b), medial expansion of basipodite haired, coupler with 2 large blunt triangular expansions. Leg 3 (Fig. 2c), medial expansion of basipodite haired, expansions of coupler large, broadly triangular, acute. Leg 4 (Figs. 2d, e), posterodistal margin of coxopodite with short row of small spines; basipodite naked medially; coupler with 2 medially directed slender acuminate spiniform processes; and most of lateral margin of medial terminal spine of endopodite article 3 finely spinulate.

Discussion. - Principal characters such as the characteristic marginal protrusions of the swimming leg couplers, the short stout medial spine of the leg 1 basipodite, and the relative lengths of the caudal setae agree so closely with the ample description of Petkovski (1986) that I have no hesitation in assigning the specimens from Mississippi and Honduras to this taxon. Petkovski (1986: 64, Abb. 18) did not observe spinules on the lateral margin of the leg 4 endopodite 3 medioterminal spine, but these are very fine and difficult to see in some of the specimens at hand.

Both the Honduras and Mississippi records are previously unpublished. Petkovski (1986) synonymized several records of $M$. ellipticus with his new species $M$. reidae. With the discovery of $M$. reidae in Mississippi the known range of this species is extended significantly northward from Central America, Mexico, and the Antilles. 


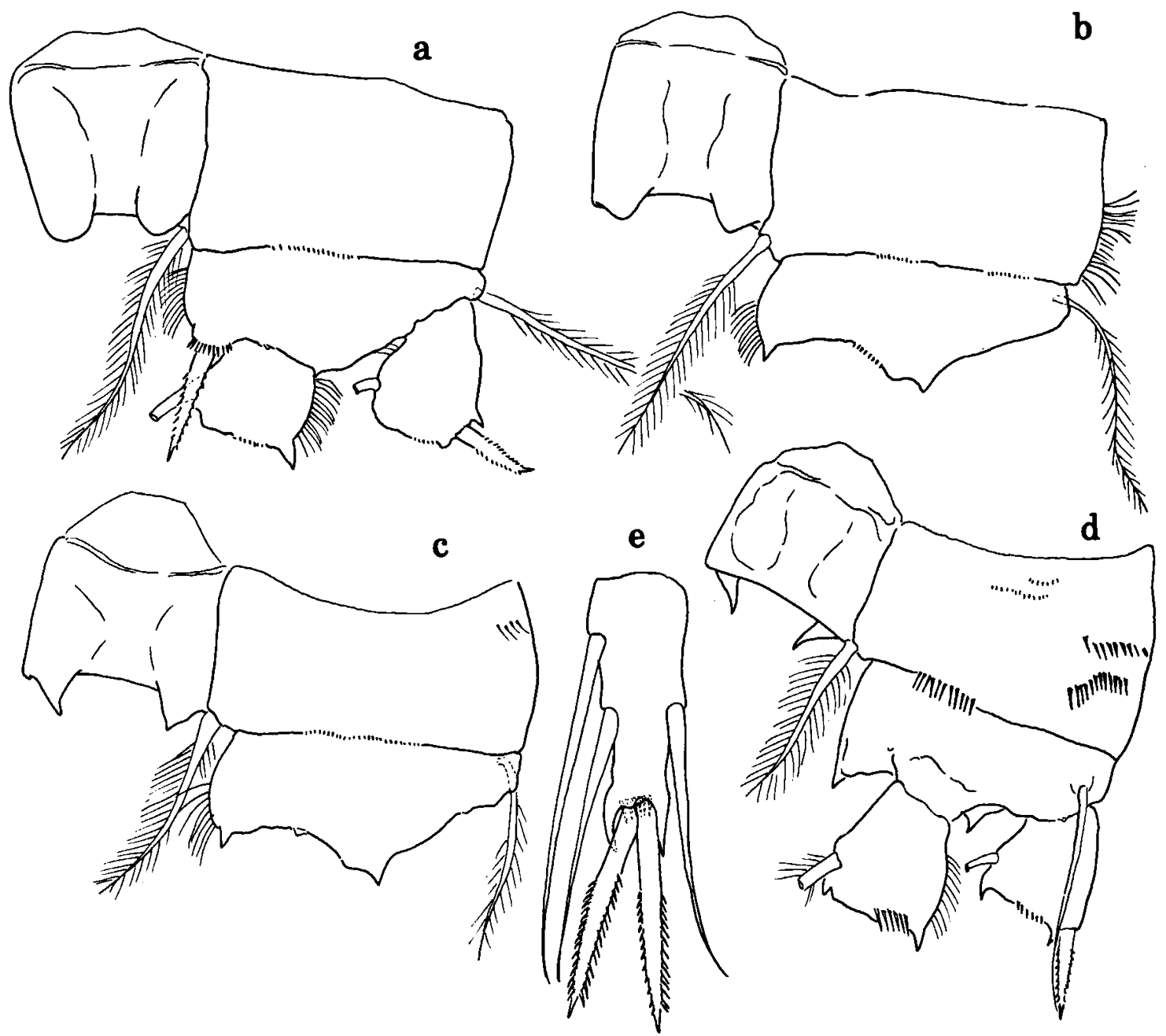

Fig. 2. Mesocyclops reidae Petkovski, 1986, dissected $\odot$ from Mississippi, USNM 252009: a, left leg 1 and coupler, anterior, most of rami not indicated; b, left leg 2 coxa-basipodite and coupler, anterior; c, left leg 3 coxa-basipodite and coupler, anterior; d, right leg 4 and coupler, posterior, most of rami not indicated; e, right leg 4 endopodite article 3, posterior, setules of setae not indicated.

\section{Mesocyclops ruttneri Kiefer, 1981}

(Figs. 3-5)

Synonymy. - Mesocyclops ruttneri Kiefer, 1981: 151, 156, 178$180,186,187$, Abb. 1 (54, 55), 14; Marten, 1990b: 681-688, tables 1-8.

Mesocyclops sp. (leuckarti-group); Marten, 1989: 232-235, table 1; 1990a: 160.

Non $M$. pehpeiensis (Hu, 1943); Dussart \& Fernando, 1985: 246; 1988: 249; Lim \& Fernando, 1985: 73, 80, 83-85, figs. 57-59.

?Mesocyclops Leuckarti pehpeiensis Hu, 1943: 115, 124-126, table II, fig. $c$.
Material. - Paratypes from the F. Kiefer Collection, Staatliches Museum für Naturkunde Karlsruhe: Mikropräparat 11101, 2 १ \& Abd. + P5, prep. Kiefer, 30 September 1980; Mikropräparat 11102, 1 \% A1-P4, prep. Kiefer, 30 September 1980; Mikropräparat 11285 , several $९$ \& $1,4 A 2$, prep. Kiefer, 11 November 1982; more than 20 adults, Glas No. 470; 1 \% from Glas No. 470, dissected on slide, prep. Reid; all from Warmwasser im Glashaus, Lunz, Österreich, 4 December 1926, coll. Klie? (question mark according to Kiefer's label).

Additional, non-paratype material: USNM 90830, 24 १ , ponds, Foochow, Fukien Province, China, April 1948, coll. C.C. Tang. USNM 250683, 1 \&, $2 \circ \sigma, 8$ copepodids, Lumtaklong Creek, Khao Yai National Park, 100 km northeast of Bang- 


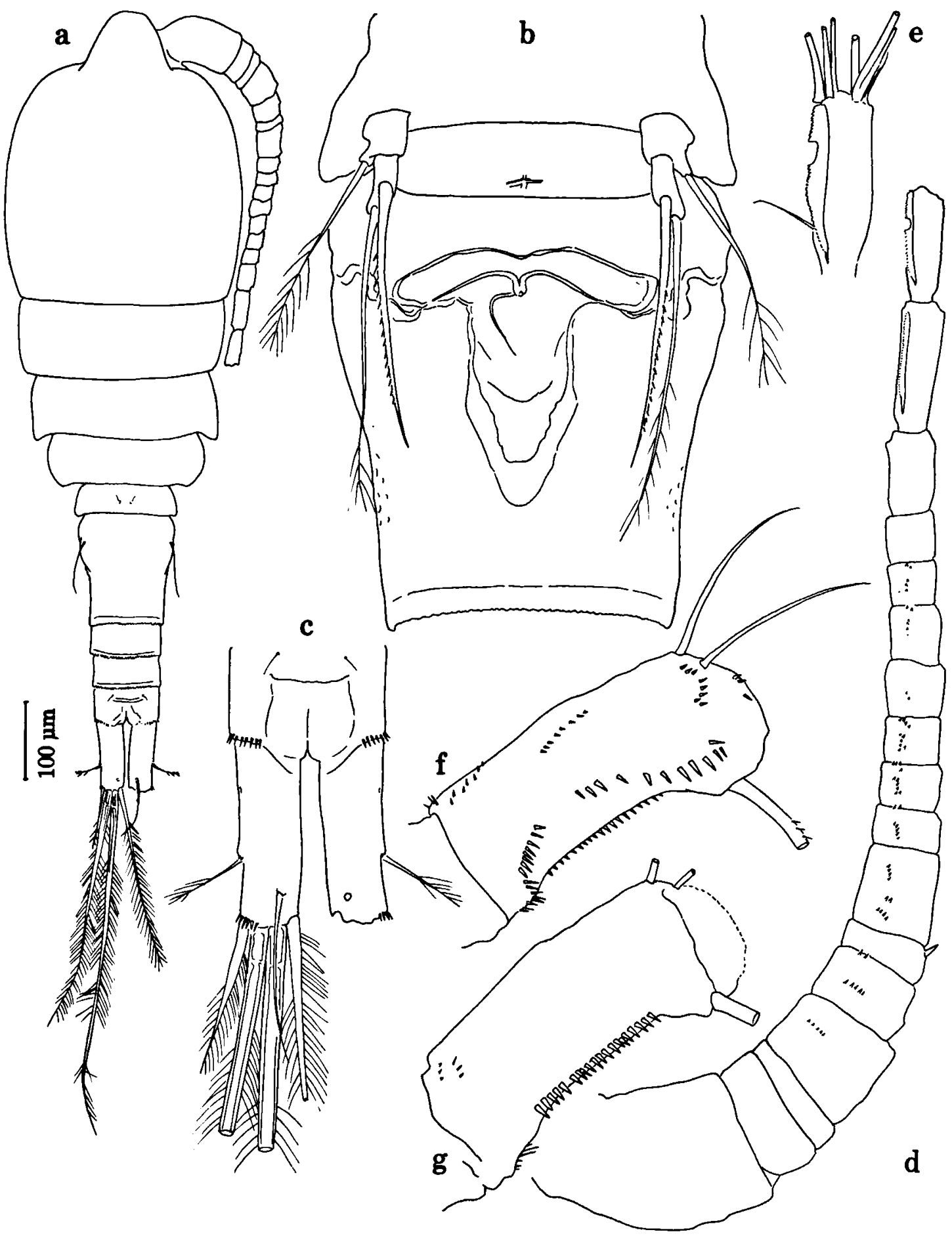

Fig. 3. Mesocyclops ruttneri Kiefer, 1981, paratype $९$ ९ from the Kiefer Collection (a, d, e, from Glas 470; b, c, from Mikropräparat 11101; f, g, from Mikropräparat 11102): a, habitus, dorsal; b, pediger 5 and genital segment, ventral; c, anal somite and caudal rami, dorsal; $d$, antennule, setae not indicated; e, antennule article 17; $f$, antenna article 1 , caudal side; $g$, antenna article 1 , frontal side. Scale applies to Fig. 3a. 
kok, Thailand, 24 January 1989, coll. T. Ishida. USNM 250565, $6 \% \%$, ricefield on Compton Farm, near New Orleans, Louisiana (after experimental introduction), 10 August 1990, coll. G.G. Marten. USNM 252010, 2 \% \&, each dissected on slide, Lagoon (canal) in Joe Brown Park, east New Orleans, Louisiana, July 1987, coll. G.G. Marten. USNM 252011, 1 \&, 8 ơ $\sigma^{\circ}, 5$ copepodids, sample No. 70, Lagoon (canal) in Joe Brown Park, east New Orleans, Louisiana, 10 June 1988, coll. G.G. Marten. USNM 252012, 1 \%, dissected on slide, and 28 $\uparrow$, sample No. 105, Lagoon (canal), Joe Brown Park, east New Orleans, Louisiana, 30 June 1988, coll. G.G. Marten. USNM 252013, 23 adult specimens, culture, originally from east New Orleans, Louisiana, 1989, coll. G.G. Marten. USNM 252014, 14 \% , 6 ơ ơ , 75 copepodids, samples 209-210, from field trials, New Orleans, Louisiana, 1989, coll. G.G. Marten. USNM 250564, 1 \%, ricefield, Bebe Farm, near Jennings, Louisiana, 9 August 1990, coll. G.G. Marten. USNM 264729, 4 ९ \&, Truc Bach Lake, Hanoi, Viet Nam, 12 January 1993, coll. Vu Sinh Nam. G.G. Marten collection: more than $20 \%$, Jennings ricefield, 26 July 1991; and more than $20 \%$, ricefield, Cleveland, Mississippi, 10 August 1991. Undissected specimens ethanol-preserved.

Description of female. - Length as given by Kiefer (1981) for type population, 1.0-1.15 mm; lengths of 10 unmounted paratype specimens, 1.0-1.28 $\mathrm{mm}$; of specimens from Fukien, China, 1.10-1.23 $\mathrm{mm}$ (median $=1.16 \mathrm{~mm}, n=10$ ); of specimen from Thailand, $1.26 \mathrm{~mm}$; of specimens from Compton Farm, Louisiana (USNM 250565), 0.98$1.19 \mathrm{~mm}$ (median $=1.04 \mathrm{~mm}, n=6)$; of specimens from Viet Nam, $1.34-1.56 \mathrm{~mm}$ (median $=1.41$ $\mathrm{mm}, n=4)$.

Redescription of paratype specimens: Habitus (Fig. 3a) slender; pediger 5 little expanded laterally, lacking ornamentation on lateral and dorsal surfaces except two hairs near dorsomedian line as present in all congeners. Genital segment (Figs. 3a, b), anterior half little expanded, few scattered shallow circular pits on lateral and dorsal surface of posterior half, surface including area posterior to leg 6 otherwise without ornamentation. Seminal receptacle (Fig. 3b) with anterior margin slightly concave, lateral arms nearly horizontal, their lateral ends slightly recurved anteriorly; posterior margins leading anteriorly from copulatory pore, more or less fused near pore in different specimens before diverging laterally; pore-canal long, curved posteriorly. Caudal rami (Figs. 3a, c) about 3.2 times longer than broad, bearing 1 or 2 tiny spines dorsal to insertion of lateral seta, and 5 or 6 larger spines dorsal and lateral to base of lateralmost terminal caudal seta; medial surface of ramus naked. Most caudal setae with fine uniform plumage, dorsal seta naked. Proportions of lengths of caudal setae as in Fig. 3a.

Antennule (Figs. 3a, d, e) when completely reflexed reaching slightly past posterior margin of pediger 2, setation like that of $M$. leuckarti; articles 4,5 , and 7-13 with rows of groups of small spines, with some variation: article 5 with 2 rows of spines on most specimens, with additional row of 3 spines on 1 antennule of female on Mikropräparat 11102. Antennules of some specimens with few shallow round pits on dorsal surface of article 1 . Hyaline membranes of antennule articles 16 and 17 finely serrate, membrane of article 17 with deep notch.

Antenna (Figs. 3f, g) general structure including setation like that of $M$. leuckarti; article 1 , in addition to basic spine pattern of genus (Van de Velde, $1984 a, b)$, caudal side with oblique row of tiny spines near medial margin, single or double irregular transverse row of 6-14 larger spines at level of proximalmost medial seta, and 2-4 spines near distal margin.

Labrum, mandible, maxillule, and maxilla as corresponding structures of $M$. leuckarti. Maxilliped (Fig. 4a) with row of small spines on article 1 and 2 groups of many small spines on article 2; setules of most setae sparse.

Leg 1 (Fig. 4b), medial expansion of basipodite lacking seta, leg otherwise similar in setation and ornamentation to leg 1 of $M$. leuckarti. Legs 2 and 3 similar to those of $M$. leuckarti except lacking group of tiny spines near proximolateral corner of posterior surface of coxopodite, present in $\boldsymbol{M}$. leuckarti (location indicated by arrow in Fig. 4c). Leg 4 (Figs. $4 \mathrm{~d}-\mathrm{h}$ ) similar to that of M. leuckarti, except medial expansion of basipodite naked and coxopodite with 2 transverse rows of spines along posterodistal margin, these rows well separated in most specimens; 1 or 2 rows of small spines on posterior surface of coxopodite near lateral margin variously developed in different specimens, these rows lacking in Louisiana specimens (Figs. 4d, e, arrows). Marginal spiniform processes of leg 4 coupler (Figs. 4d, g, h) more or less triangular, 


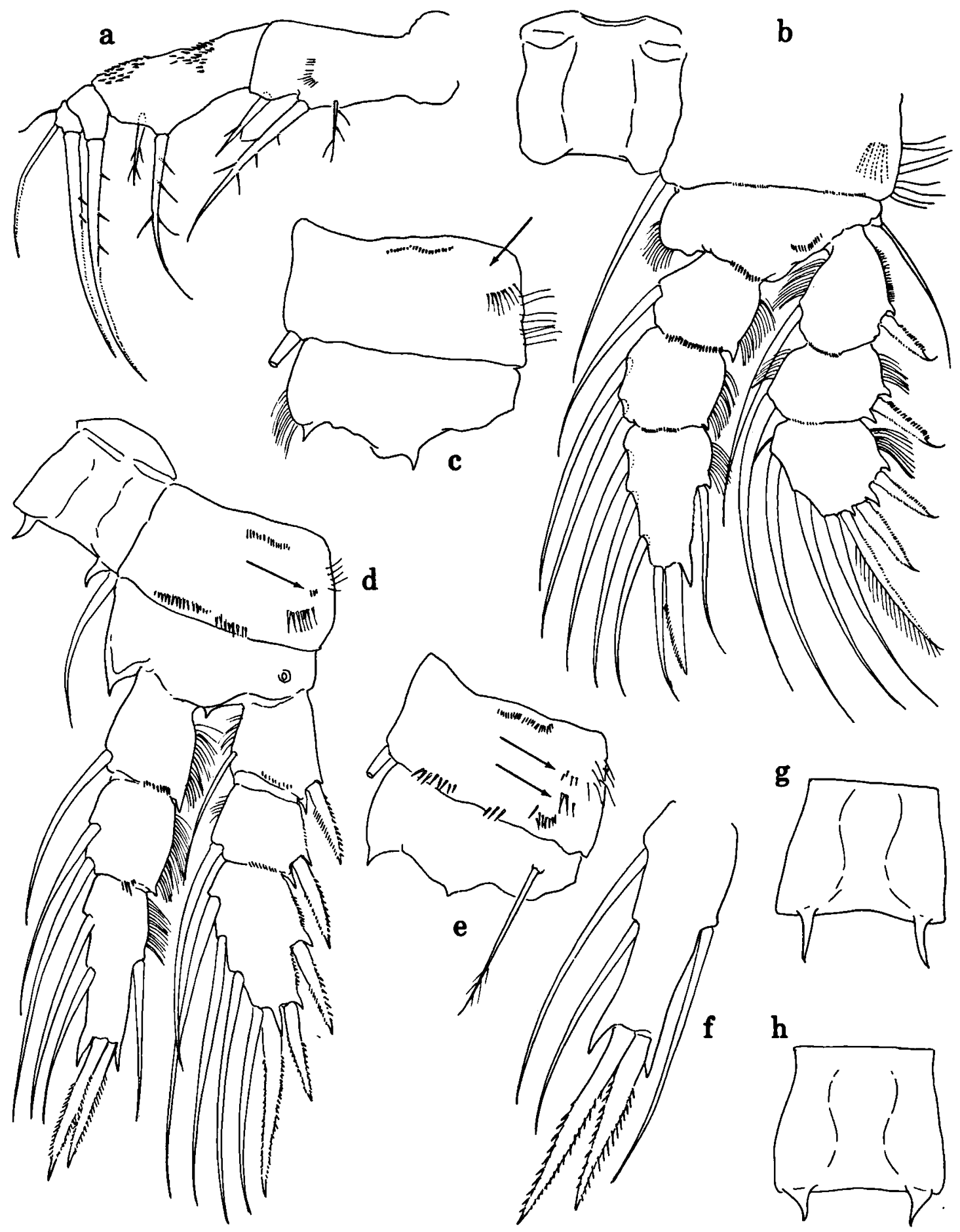

Fig. 4. Mesocyclops ruttneri Kiefer, 1981, paratype $\odot \odot$ from the Kiefer Collection (a, b, d from Glas 470; c, e, f, g, h from Mikropräparat 1102; g, h from different specimens): a, maxilliped; b, leg 1 and coupler, anterior; c, leg 2 coxa-basipodite, posterior; d, leg 4 and coupler, posterior; e, leg 4 coxa-basipodite, posterior; f, leg 4 endopodite article 3; g, h, leg 4 couplers. 


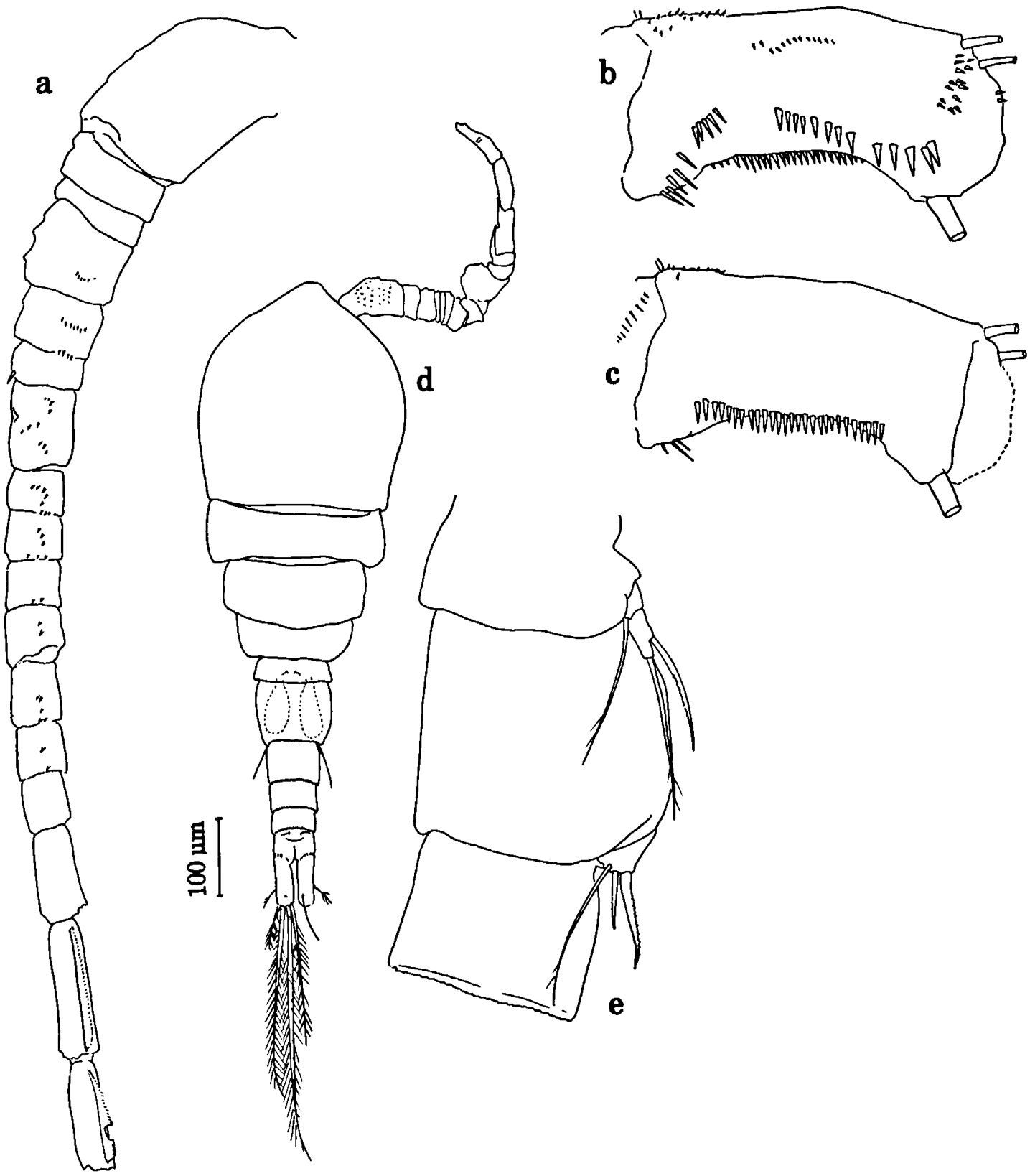

Fig. 5. Mesocyclops ruttneri Kiefer, 1981, a-c, dissected $q$ from Louisiana, USNM 252012; d, e, paratype $\sigma$ from the Kiefer Collection, Glas 470: a, antennule, setae omitted; b, antenna article 1, caudal side; $c$, antenna article 1, frontal side; $d$, habitus, dorsal; $e$, pedigers 5, 6 and succeeding urosomite. Scale applies to Fig. 5d.

always with acute curved slender tip. Leg 5 (Fig. $3 \mathrm{~b})$, seta of article 1 shorter than seta of article 2 , seta and spine of article 2 subequal in length.

The antennule spine patterns (Figs. 3d, 5a) varied somewhat in the number and arrangement of spines on each article, but the general pattern was remark- ably constant in the individuals and populations examined. The variation of antenna spine patterns (Figs. 3f, g, 5b, c) between distant populations was no greater than the within-population variation. The shape of the spiniform processes of the leg 4 coupler (Figs. 4d, g, h) varied from bluntly trian- 
gular to very slender, usually similar to Fig. 4 d.

Description of male. - Lengths of paratypes from the Kiefer Collection Glas No. 470, 0.73-0.89 mm (median $=0.82 \mathrm{~mm}, n=10$ ). Habitus (Fig. 5d) slender. Antennule geniculate, setation and aesthetascs of articles 1-4 similar to that described for male of $M$. leuckarti by Gurney (1933: 290, fig. 1865). Dorsal surface of antennule article 1 of all specimens examined with several transverse rows of round pits. Mouthparts and legs $1-5$ as in female. Leg 6 (Fig. 5e) composed of small trapezoidal flap bearing 1 stout ventral spine, 1 short median seta, and 1 long dorsal seta reaching posterior margin of succeeding somite.

Discussion. - Specimens of Mesocyclops ruttneri were first collected in Austria in a greenhouse, which had been destroyed by the time that the original description was published (Kiefer, 1981). Kiefer (1981) speculated that the species must be Asian.

Dussart \& Fernando $(1985,1988)$ and Lim \& Fernando (1985) described a species from Australia, Burma, Indonesia, Malaysia, and Sri Lanka and identified it as $M$. pehpeiensis $\mathrm{Hu}, 1943$, a poorly known species originally described from China. They synonymized $M$. ruttneri with $M$. pehpeiensis on the basis of similarities between Kiefer's description and their material, apparently without comparing type material of $M$. ruttneri. These authors' figures of various populations assigned to $M$. pehpeiensis differ among themselves in several respects, particularly in the antenna spine patterns and the indications of hairs or lack thereof on the medial extension of the leg 4 basipodite. Whether or not the populations from these mutually distant localities are all conspecific, the description of each differs in several respects from $M$. ruttneri.

In Sri Lankan “M. pehpeiensis" (Dussart \& Fernando, 1988) the caudal side of antenna article 1 is shown as having a group of 5 tiny spines more or less at the level of the more proximal medial seta, in contrast to the single or double row of 6-14 small spines near the corresponding location and the additional 2-4 small spines near the distal caudal margin that are always present and easy to see in M. ruttneri.

Figures by Dussart \& Fernando (1986, locality not indicated) and Lim \& Fernando (1985, Malaysia) for the caudal side of antenna article 1 of " $M$. pehpeiensis" show a large diffuse group rather than a row of spines at the level of the proximal medial seta, and no spines near the distal margin. The two groups of tiny spines at a level distal to the longitudinal row of spines on the frontal side of this article shown by Dussart \& Fernando (1986) and Lim \& Fernando (1985) are not present in $M$. ruttneri.

Seminal receptacles also differ: in $M$. ruttneri the lateral arms are narrower and slightly recurved anteriorly at the lateral ends. The posterior margins, leading from the copulatory pore, in M. ruttneri are always directed anteriorly and usually conjoined to some extent from the pore before diverging laterally in a sharp curve, while in all representations of "M. pehpeiensis" these margins curve laterally directly from the pore.

In $M$. ruttneri there are always one or two small spines on the caudal ramus proximal to the insertion of the lateral caudal seta. Spines at this location are shown by neither Dussart \& Fernando (1988) nor Lim \& Fernando (1985).

Finally, Lim \& Fernando (1985) show the medial expansion of the leg 4 basipodite as thickly haired.

Hu's (1943) original description of $M$. pehpeiensis provides few of the morphological details that are today considered necessary to distinguish species of the genus. Hu gave the lengths of female specimens as $1.525-1.710 \mathrm{~mm}$. He reported the caudal ramus of $M$. pehpeiensis as 3.5-4.0 (mean 3.7) times longer than broad, thus slightly narrower than in the populations of $M$. ruttneri examined. Otherwise there is no discernible difference from M. ruttneri. Subsequent descriptions of Asian Mesocyclops populations ascribed to $M$. pehpeiensis by Tai \& Chen (1979) and by Kim \& Chang (1989) unfortunately have not provided sufficient detail to clarify the problem (Reid \& Kay, 1992). In view of the demonstrated presence in Asia of several populations that differ from each other in a series of microcharacters but that are all more or less congruent with Hu's description, comparison of topotype material is essential for a final determination of the identity of his species with $M$. ruttneri, or with subsequently described populations of Mesocyclops from Asia. 
Mesocyclops papuensis Van de Velde, 1987 from Papua New Guinea is also very similar to $M$. ruttneri. There are slight differences in the antenna article 1 spine pattern, $M$. papuensis having a diffuse group of small spines on the caudal side at the level of the medial setae (Van de Velde, 1987: 159 , figs. 45,47$)$ rather than the single or double rows of spines in $M$. ruttneri. In $M$. papuensis, the medial terminal spine of leg 4 endopodite article 3 has a few (4) large spinules near the midlength of its lateral margin, but in $M$. ruttneri nearly the entire length of the margin of this spine is spinulate. Also in $M$. ruttneri, the leg 4 endopodite 3 medial terminal spine is always distinctly longer than the lateral terminal spine, but these spines are subequal in M. papuensis. Mesocyclops papuensis of course also resembles the general description of $M$. pehpeiensis.

These records of $M$. ruttneri from the southern U.S.A. and Asia are the first outside Austria. The discoveries in China, Thailand, and Viet Nam probably represent native populations. The population in Austria was undoubtedly introduced into the greenhouse, and the species has never been collected elsewhere in Europe (Kiefer, 1981). The populations in Louisiana and Mississippi were likely introduced, possibly either along with imported tropical aquatic plants or fish, or somehow with rice. Wild populations of this species were collected in 1990 and 1991 in ricefields near Jennings, Louisiana, about $300 \mathrm{~km}$ west of New Orleans, and near Cleveland, Mississippi, about $400 \mathrm{~km}$ north of New Orleans. The species seems to be well established and probably spreading in the region. Adults originally collected in New Orleans were introduced into Jennings ricefields in 1990 and into both Jennings and Cleveland ricefields in 1991 as part of mosquito-control experiments (G.G. Marten, personal communications, 1990, 1991).

Mesocyclops ruttneri, like M. americanus Dussart, 1985, is a member of the leuckarti-group. It is the second member of this group, after M. americanus, to be recorded in the contiguous U.S.A. and Canada. Therefore the assumption by Dussart (1985) and Dussart \& Fernando (1990) that all records of $M$. leuckarti in these countries must refer to $M$. americanus is not quite the case. The small aquatic fauna of non-lacustrine wetlands in most of North America is inadequately known. Researchers should be alert for the possibility of encountering additional species of the genus.

Genus Diacyclops Kiefer, 1927, 1928, char. emend. Morton, 1985, Reid et al., 1989

Diacyclops bernardi (Petkovski, 1986)

(Figs. 6-8)

Synonymy. - Mesocyclops bernardi Petkovski, 1986: 47, 48, 66-71, 72, Abb. 22-33; 1988: 40, 63; Sket, 1988: 79, table 1; Reid, 1990: 180, table I; Marten, 1990b: 681.

Mesocyclops (?) bernardi; Dussart, 1987: 153, 155.

Material. - USNM 251979, 1 \& on slide, Swale No. 1, Mail Box 274, Chef Menteur Highway, east New Orleans, Louisiana, U.S.A., 14 November 1989, coll. G.G. Marten. USNM 259530, $1 \%$, ethanol-preserved, pond at side of Mérida-Progreso Highway, $\mathrm{km} \mathrm{27}$, in front of PEMEX plant, Mérida, México, $16 \mathrm{July}$ 1992, coll. M.F. Suárez and L. Bracamonte.

Description of female. - Length of Louisiana specimen $1.01 \mathrm{~mm}$; of Mérida specimen $0.95 \mathrm{~mm}$. Habitus (Figs. 6a-c) as described by Petkovski (1986), except pediger 4 laterally bilobed. Pediger 5 (Figs. 6a-c) approximately as broad in dorsal view as broadest part of genital segment, little produced posteriorly, lacking ornamentation except 2 dorsal hairs near midline. Genital segment (Figs. 6a-d) $125 \mu \mathrm{m}$.long, $138 \mu \mathrm{m}$ broad at broadest part, with 3 dorsal papillae and 3 dorsal hairs, otherwise lacking ornamentation. Seminal receptacle (Fig. 6d), anterior outline difficult to distinguish, posterior expansion little developed in both specimens. Copulatory pore (Figs. 6d, e) tiny, unsclerotized; pore-canal slender, slightly curved; medial half of margin of each lateral canal curved posteriorly, lateral half slightly recurved anteriorly. The structures of the pore and canals were not distinguished by Petkovski (1986: 67, Abb. 24), but a sketch of a paratype female sent by B.H. Dussart (in litt., 1991) shows a structure similar to those of the specimens from Louisiana and Mexico. Caudal rami (Figs. 6a, g, h) 2.65 times longer than broad, lacking ornamentation on medial surfaces and at base of lateral seta, but having 6 tiny spines at base of 


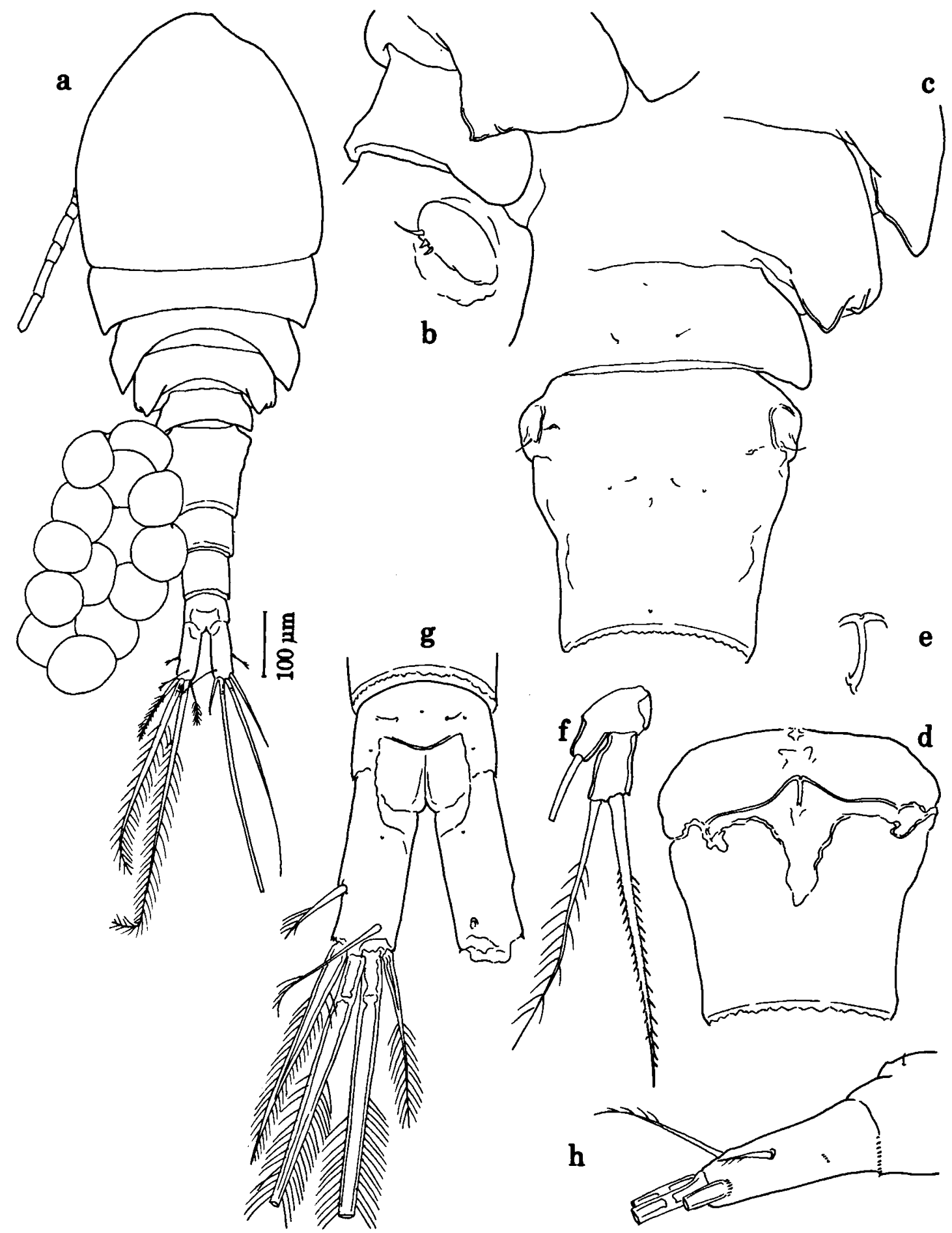

Fig. 6. Diacyclops bernardi (Petkovski, 1986), $\odot$ from Louisiana, USNM 251979: a, habitus, dorsal; b, posterior prosome and anterior urosome, right lateral; c, posterior prosome and anterior urosome, dorsal; d, genital segment, ventral; e, copulatory pore and porecanal, lateral-oblique, showing ventral curve; f, leg 5; g, anal somite and caudal rami, dorsal; $h$, right caudal ramus, lateral. Scale applies to Fig. 6a. 
lateralmost terminal seta. In Louisiana specimen, right caudal ramus also with dorsoventral lateral row of 3 tiny spines and 1 papilla midway between base of ramus and lateral seta; left caudal ramus with similar papilla but lacking spines; Mexican specimen with reverse arrangement. Specimen from Louisiana: both medial terminal caudal setae of right caudal ramus broken; lengths of setae of left caudal ramus in $\mu \mathrm{m}$, dorsal 65 , lateral 36 , medialmost to lateralmost terminal $82,400,312,115$. Specimen from Mexico: lengths of caudal setae, dorsal 58, lateral 35, medialmost to lateralmost terminal 73, 380, 296, $104 \mu \mathrm{m}$. Lateralmost terminal caudal seta about 2 times thicker at base than medialmost terminal caudal seta. All setae with uniformly fine, closely set setules. Specimen from Louisiana with paired egg sacs, each with 17 eggs.

Antennule (Figs. 6a, 7a, b) of 16 articles in both specimens, articles numbered in Roman numerals (with numbers of setae in parentheses): I(8), II(4), III(2), IV(5), V(3), VI(1), VII(2), VIII(1), IX(1), $\mathrm{X}(0), \mathrm{XI}(1), \mathrm{XII}(1), \mathrm{XIII}(1), \mathrm{XIV}(2), \mathrm{XV}(1)$, XVI(7). Article 6 with spine, articles 12 and 15 each with aesthetasc; slender aesthetasc of article 15 reaching nearly midlength of article 16 . Hyaline membrane of article 15 narrow, finely serrate; membrane of article 16 broad, more coarsely serrate distally. Surface of articles otherwise lacking ornamentation, except row of small spines on article 1 . Number of 16 articles resulting from apparent fusion of former articles 13 and 14, by analogy with location and numbers of setae of antennules of Mesocyclops leuckarti as redescribed by Van de Velde (1984a) and of Diacyclops navus as redescribed by Reid et al. (1989).

Antenna (Figs. 7c, d) similar in general structure and number of setae to antenna of $D$. navus (Reid et al., 1989: 340, fig. 2b); article 1 bearing, in addition to 2 short slender setae and 1 long stout seta on distal border: 1 short row of spines along proximal part of lateral margin and 2 rows of spines along proximal part of medial margin, 1 short longitudinal row of spines on frontal side near lateral margin and 2 longitudinal curved rows of spines on caudal side.

Mandible (Fig. 7e) similar to that of D. navus, lacking spines near palp, with 1 row of slender spines near base of teeth of pars incisiva. Maxillule (Fig. 7f) lacking spines on surface of palp. Claw of maxilla (Fig. $7 \mathrm{~g}$ ) with stout teeth along middle of margin, otherwise similar to maxilla of $D$. navus. Maxilliped (Fig. 7h) with 1 longitudinal and 1 transverse row of spines on article 2 .

Legs 1-4 (Figs. 8a-d) with triarticulate rami, spine formula $2,3,3,3$, seta formula $4,4,4,4 / 3$. Leg 1 much as described by Petkovski (1986: 67, Abb. 27), additionally with medial expansion of basipodite haired, 2 short diagonal rows of spines on anterior surface of basipodite, and lateral spines of exopodite somewhat stouter than in specimens from San Andrés. Legs 2 and 3 similar to each other, strikingly larger than legs 1 and 4, exopodites and lateral spines of exopodites very stout. Leg 4 much as described by Petkovski (1986), except lateral spines of exopodite of specimens from Louisiana and Mexico relatively stouter. Coxa-basipodite of Louisiana specimen ornamented as illustrated. Leg 4 basipodite of specimen from Mexico with similar ornamentation, except row of spines on posterodistal border longer, extending along middle $2 / 3$ of border. Louisiana specimen: right leg 4 exopodite article 3 with 2 setae and 1 socket; left exopodite article 3 with 4 setae, next distalmost seta short; both articles additionally with 3 large spines. Specimen from Mexico with 4 setae on each exopodite article 3.

Leg 5 (Fig. 6f), lateral setae of article 1 of both legs broken in Louisiana specimen and, in specimen from Mexico, slightly longer than terminal seta of article 2 . In both specimens, terminal spine and seta of article 2 reaching about midlength of genital segment. Leg 6 (Fig. 6b) consisting of ovoid plate lacking surface ornamentation and bearing 2 spines and 1 short dorsal seta.

Discussion. - Examination of the specimens of $D$. bernardi from Louisiana and Mexico confirms and reinforces Petkovski's (1986) observation that this species combines morphological features of several genera. These genera are Diacyclops, Mesocyclops, and Thermocyclops as presently defined; cf. recent diagnoses of Diacyclops by Kiefer (1978) and Morton (1985), and of Mesocyclops and Thermocyclops by Kiefer (1978). Petkovski (1986) assigned 


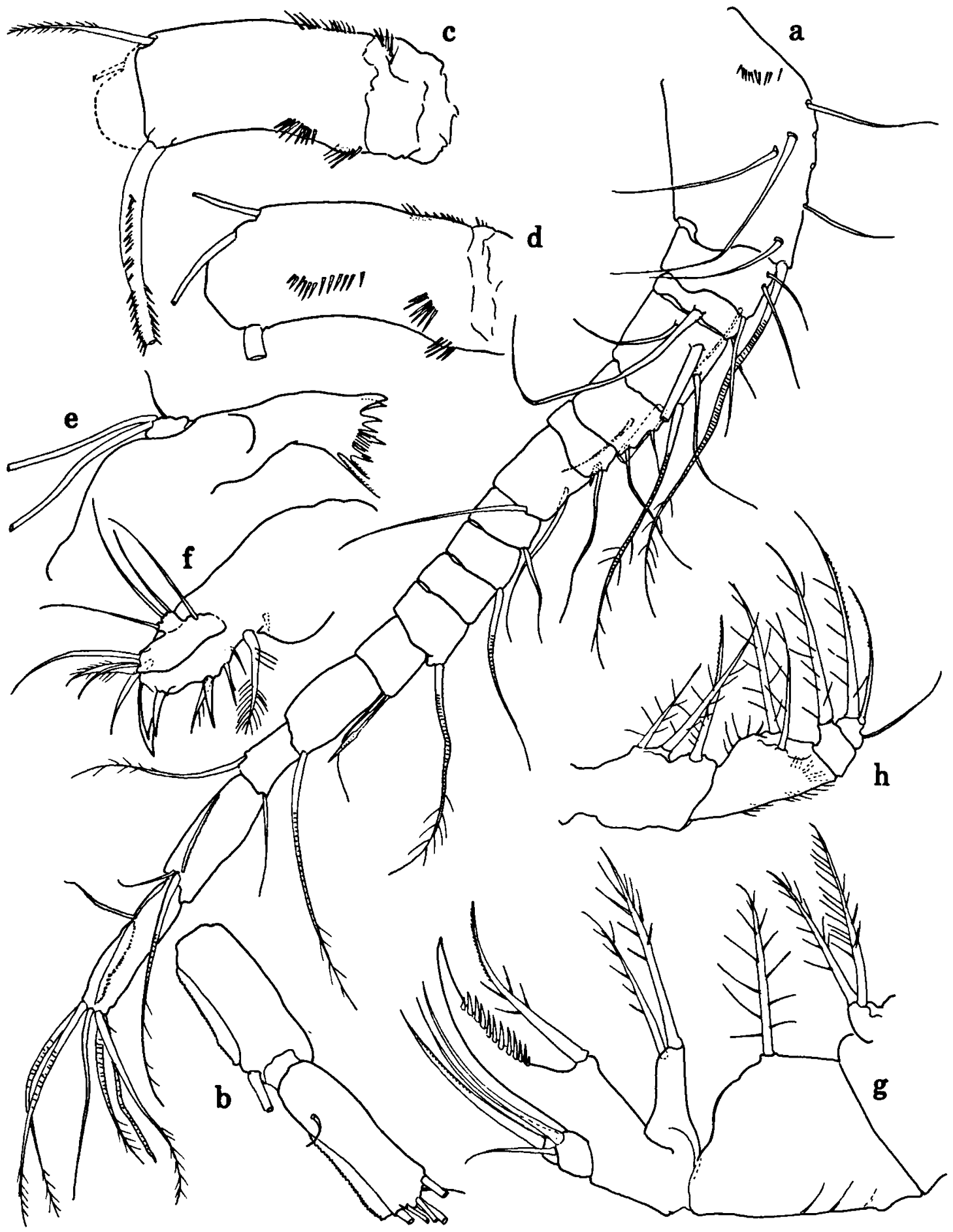

Fig. 7. Diacyclops bernardi (Petkovski, 1986), $Q$ from Louisiana, USNM 251979: a, antennule; b, antennule articles 15-16; c, antenna article 1, frontal side; $d$, antenna article 1 , caudal side; e, mandible; $f$, maxillule; $g$, maxilla; $h$, maxilliped. 


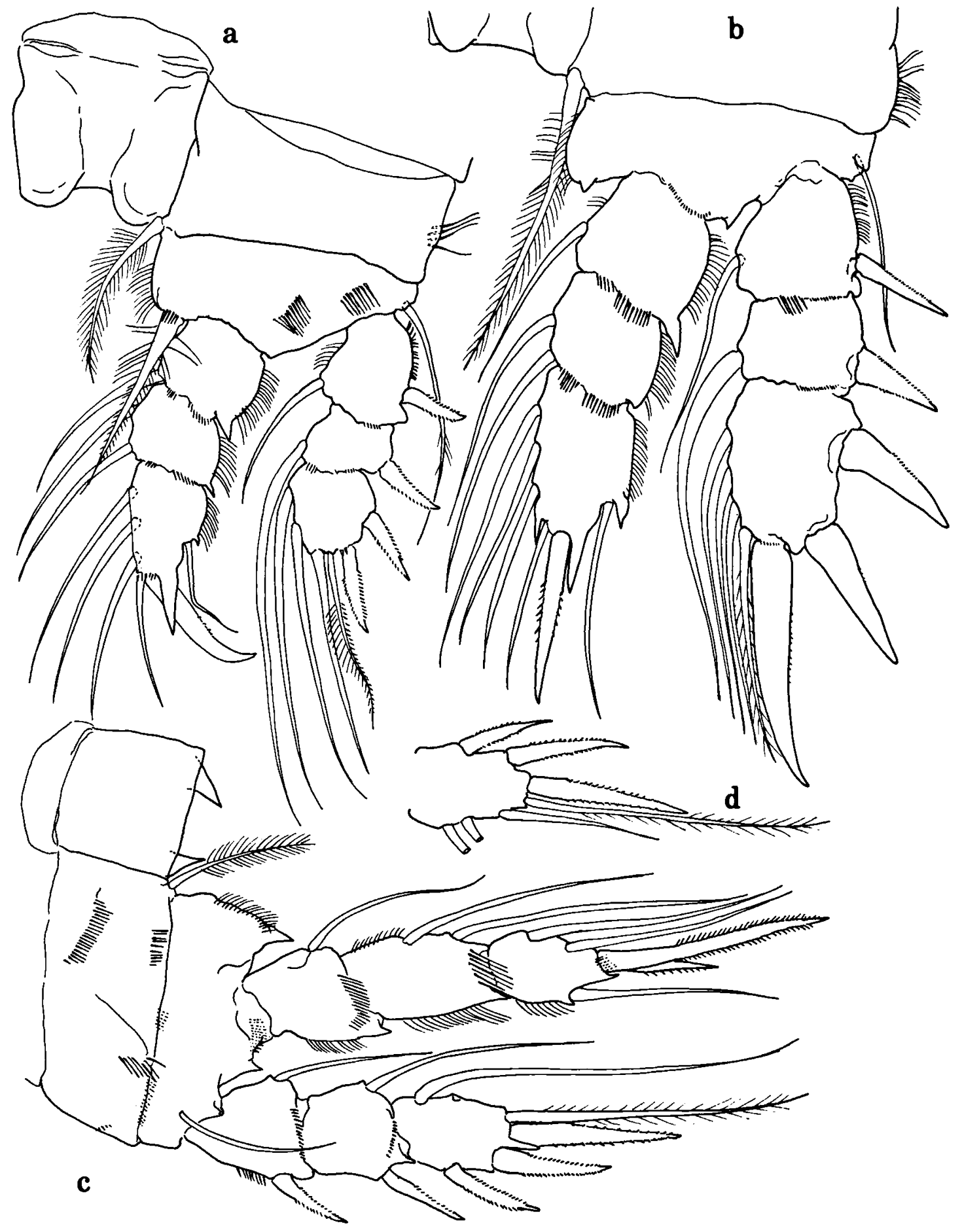

Fig. 8. Diacyclops bernardi (Petkovski, 1986), $\odot$ from Louisiana, USNM 251979: a, left leg 1 and coupler, anterior; b, left leg 2 and part of coupler, anterior; c, left leg 4 and coupler, posterior; d, right leg 4 exopodite article 3, posterior. Plumage of most setae omitted for clarity. 
the species to Mesocyclops on the basis of the structures of the seminal receptacle and the leg 4 coupler, although he called attention to the similarity of the terminal spines of the leg 4 endopodite and the terminal placement of the medial spine of leg 5 to species of Thermocyclops. Dussart (1987), having examined some of Petkovski's specimens, advanced a tentative opinion that the species is better placed in Thermocyclops. Dussart mentioned that the structure of the seminal receptacle and leg 5 , the fine serration of the hyaline membrane of the antennule, and the ornamentation of article 1 of the antenna agree better with Kiefer's $(1927,1978)$ diagnoses of that genus.

The distinctly sclerotized lateral arms and the shape of the posterior expansion of the seminal receptacle resemble some species of all three genera, e.g., Mesocyclops meridianus (Kiefer, 1926), M. reidae, Thermocyclops tenuis (Marsh, 1910), T. inversus Kiefer, 1936b, Diacyclops palustris Reid, 1988 , and $D$. navus. The structure of the receptacle therefore supports no argument for inclusion of this species in a particular genus.

The antennule is composed of 17 articles in species of Mesocyclops and Thermocyclops, and I am unaware of any example of reduction of article number in those genera. Most of the specimens collected from San Andrés have the antennule of 16 articles, with one having 17 articles (T.K. Petkovski, in litt., 1991). The number of 16 articles appears to be most characteristic for $D$. bernardi. Reduction and variation in antennule article number is a common phenomenon in species of Diacyclops.

The structure of the hyaline membrane of the antennule likewise offers little basis for generic assignation because all three genera include some species with a similar finely serrate, unnotched membrane. The membrane is broader than in known species of Thermocyclops and Diacyclops.

The ornamentation of article 1 of the antenna of $D$. bernardi differs substantially from the basic pattern found in Mesocyclops (Van de Velde, 1984a, b). On the proximal part of the medial margin, there is a row of large spines rather than the tiny spines found at this location in many (though not all) species of Mesocyclops, and these spines do not continue as a row on the caudal side as is the usual case in Mesocyclops. On the frontal side there is a short row of 8 spines at about the proximal third, rather than the long longitudinal row of some 20 or more spines usually present in Mesocyclops, and the proximal transverse row of tiny spines found in Mesocyclops is not present in $D$. bernardi. The pattern in $D$. bernardi is less ornate than in many species of Thermocyclops, although all the spines are long, rather than being reduced to tiny "teeth" as in many species of the latter genus (Fiers \& Van de Velde, 1984). The pattern of $D$. bernardi is, however, very similar to the patterns of Diacyclops bicuspidatus (Claus, 1857) sensu stricto and D. bicuspidatus odessanus (Schmankevitch, 1875), as presented by Fiers \& Van de Velde (1984), and also to $D$. navus as redescribed by Reid et al. (1989), and D. palustris.

The terminal article of the antennule of $D$. bernardi is about 4 times longer than broad, similar to the usual proportions of this article in species of Mesocyclops. The corresponding article in Thermocyclops is usually about 2 times longer than broad, serving as a useful distinction between the two genera (J.F. Saunders, III, pers. comm., 1984; Reid, 1985). In Diacyclops, the proportions of this article differ considerably, from about 3.2 times longer than broad in $D$. navus and $D$. palustris to as short as 2 times longer than broad in $D$. languidoides (Lilljeborg, 1901) sensu lato as redescribed by Reid et al. (1991).

In known species of Mesocyclops and Thermocyclops, the medialmost terminal caudal seta usually is much longer than the caudal rami and is consistently longer than the lateralmost terminal caudal seta. In species of Diacyclops this seta is usually short, as in $D$. bernardi.

Many species of Diacyclops possess a dorsoventral row or comb of small spines on the lateral surface of the caudal ramus about equidistant between the base of the ramus and the lateral seta, similar to the spines of the specimens of $D$. bernardi from Louisiana and Mexico. Such a row of spines has not to my knowledge been described in species of Mesocyclops or Thermocyclops. However, I have observed a short row of spines at this location in two of hundreds of specimens of $M$. ruttneri examined from Louisiana and Mississippi. 
The leg 4 endopodite article 3 in Mesocyclops is usually 3-4 times longer than broad, and the two terminal spines are subequal in length. The corresponding article in $D$. bernardi is short by comparison and the terminal spines are of greatly different lengths, as is the case in many species of Thermocyclops and Diacyclops.

The large triangular spiniform processes of the leg 4 coupler of $D$. bernardi are similar to structures present in many species of Mesocyclops and different from the rounded processes in many Thermocyclops. Species of Diacyclops usually have no or only small rounded processes on the leg 4 coupler, which may be ornamented also with small spines on its surface.

The robustness of the swimming legs and their lateral spines, especially legs 2 and 3 in $D$. bernardi, is an unusual feature for all these genera and may be an adaptation for a benthic and possibly primarily subterranean existence.

In the present state of our concept of genera of Cyclopidae, the structure of the fifth leg is still afforded great importance. In $D$. bernardi the medial spine of article 2 of the fifth leg is clearly subterminal in accordance with the diagnoses of Thermocyclops and Diacyclops, but not with Mesocyclops in which the medial spine is inserted about midlength of the article. The terminal spines of the fifth legs of several species presently included in Diacyclops are comparatively long. For instance, the spine in D. navus frequently approaches or exceeds the length of the terminal seta and may reach midlength of the genital segment in the female and nearly to leg 6 in the male (Reid et al., 1989).

In summary, the nature of several characters has persuaded me to propose transfer of this species to the genus Diacyclops. These are: the number of articles of the antennule, which is usually 16 rather than 17; the ornamentation of the antenna; the structure of the seminal receptacle; the dorsoventral row of small spines on the lateral surface of the caudal ramus; and the structures of the fourth and fifth legs.

The record of $D$. bernardi from New Orleans, from an intermittently flooded swale, was previously reported by Marten (1990b). On San Andrés Island, collections were made from pools and a cave (Petkovski, 1986).

\section{Acknowledgements}

Several colleagues provided cordial assistance, answering inquiries and lending or donating specimens: Drs. Bernard $\mathrm{H}$. Dussart, C. Herbert Fernando, Teruo Ishida, Gerald G. Marten, Trajan K. Petkovski, James R. Reddell, Marco F. Suárez, Vu Sinh Nam, and Harry C. Yeatman. Dr. Hans-Walter Mittmann lent specimens and some of Dr. Friedrich Kiefer's original sketches from the Kiefer Copepod Collection in the Staatliches Museum für Naturkunde Karlsruhe. Dr. Gerald G. Marten and his technical assistants made the extensive collections which provided the impetus for this report.

\section{References}

Burmeister, H., 1834. Beiträge zur Naturgeschichte der Rankenfüsser (Cirripedia): 1-60, Taf. 1, 2 (G. Reimer, Berlin).

Claus, C., 1857. Das genus Cyclops und seine einheimischen Arten: 1-40, Taf. I-III (Inaugural-Dissertation, Marburg).

Dana, J.D., 1853. Crustacea. In: United States Exploring Expedition during the years $1838,1839,1840,1841,1842$, under the command of Charles Wilkes, U.S.N., 13(2): 687-1618 (C. Sherman, Philadelphia). Folio Atlas, pls. 1-96, published 1855.

Dussart, B.H., 1985. Le genre Mesocyclops (Crustacé, Copépode) en Amérique du Nord. Can. J. Zool., 63(4): 961-964.

Dussart, B.H., 1987. Sur quelques Mesocyclops (Crustacea, Copepoda) d'Amérique du Sud. Amazoniana, 10(2): 149161.

Dussart, B.H. \& C.H. Fernando, 1985. Les Copépodes en Sri Lanka (Calanoïdes et Cyclopoïdes). Hydrobiologia, 127(3): 229-252.

Dussart, B.H. \& C.H. Fernando, 1986. The Mesocyclops species problem today. Syllogeus, 58: 288-293.

Dussart, B.H. \& C.H. Fernando, 1988. Sur quelques Mesocyclops (Crustacea, Copepoda). Hydrobiologia, 157(3): 241264.

Dussart, B.H. \& C.H. Fernando, 1990. A review of the taxonomy of five Ontario genera of freshwater cyclopoid Copepoda (Crustacea). Can. J. Zool., 68(12): 2594-2604.

Fiers, F. \& I. van de Velde, 1984. Morphology of the antenna and its importance in the systematics of the Cyclopidae. Crustaceana, Suppl. 7(2): 182-199.

Forbes, S.A., 1891., On some Lake Superior Entomostraca. Annual Report of the Commissioner of Fish and Fisheries for 1887: 701-718, pls. I-IV (Government Printing Office, Washington).

Gurney, R., 1933. British freshwater Copepoda, 3: 1-334 (Ray Society, London).

Herrick, C.L., 1887. Contribution to the fauna of the Gulf of Mexico and the South. Mem. Denison scient. Ass., 1(1): 356, pls. I-VII, IX.

Hu, Y.T., 1943. Notes on fresh-water copepods from Pehpei, Szechwan. Sinensia, Nanking, 14(1-6): 115-128. 
Kiefer, F., 1926. Beiträge zur Copepodenkunde (IV). 9. Neue Cyclops-Arten. Zool. Anz., 69(1/2): 21-25.

Kiefer, F., 1927. Versuch eines Systems der Cyclopiden. Zool. Anz., 73(11/12): 302-308.

Kiefer, F., 1928. Über Morphologie und Systematik der Süsswasser-Cyclopiden. Zool. Jahrb., Abt. Syst. Ökol. Geogr. Tiere, 54(5/6): 495-556.

Kiefer, F., 1936a. Brasilianische Ruderfusskrebse (Crustacea Copepoda), gesammelt von Herrn Dr. Otto Schubart. V. Mitteilung. Zool. Anz., 116(1/2): 31-35.

Kiefer, F., 1936b. Brasilianische Ruderfusskrebse (Crustacea Copepoda), gesammelt von Herrn Dr. Otto Schubart. II. Mitteilung. Zool. Anz., 114(5/6): 129-133.

Kiefer, F., 1978. Das Zooplankton der Binnengewässer, 2. Freilebende Copepoda. Binnengewässer, 26(2): 1-343.

Kiefer, F., 1981. Beitrag zur Kenntnis von Morphologie, Taxonomie und geographischer Verbreitung von Mesocyclops leuckarti auctorum. Arch. Hydrobiol., Suppl 62 (Monogr. Beitr.), 1: 148-190.

Kim, H.S. \& C.Y. Chang, 1989. Freshwater cyclopoid copepods (Cyclopoida, Cyclopidae) of Korea. Korean J. syst. Zool., 5(2): 225-256.

Lilljeborg, W., 1901. Synopsis specierum huc usque in Suecia observatarum generis Cyclopis, sive Bidrag till en Öfversigt af de inom Sverige iakttagna arterna af släktet Cyclops. K. svenska VetenskAkad. Handl., (N. F.) 35(4): 1-118, pls. I-VI, 2 tables.

Lim, R.P. \& C.H. Fernando, 1985. A review of Malaysian freshwater Copepoda with notes on new records and little known species. Hydrobiologia, 128(1): 71-89.

Marsh, C.D., 1910. A revision of the North American species of Cyclops. Trans. Wisconsin Acad. Sci. Arts Lett., 16(2): 1067-1136.

Marten, G.G., 1989. A survey of cyclopoid copepods for control of Aedes albopictus larvae. Bull. Soc. Vector Ecol., 14(2): 232-236.

Marten, G.G., 1990a. Issues in the development of cyclops for mosquito control. In: M. F. Uren, J. Blok \& L. H. Manderson (eds.), Proceedings of the 5th Symposium on Arbovirus Research in Australia: 159-164 (CSIRO \& Queensland Inst. Med. Research, Queensland).

Marten, G.G., 1990b. Evaluation of cyclopoid copepods for Aedes albopictus control in tires. J. amer. Mosquito Control Ass., 6(4): 681-688.

Morton, D.W., 1985. Revision of the Australian Cyclopidae (Copepoda: Cyclopoida), I. Acanthocyclops Kiefer, Diacyclops Kiefer and Australocyclops, gen. nov. Aust. J. mar. Freshwat. Res., 36: 615-634.

Pesce, G.L., 1985. Amsterdam Expeditions to the West Indian Islands, Report 45. Cyclopids (Crustacea, Copepoda) from West Indian groundwater habitats. Bijdr. Dierk., 55(2): 295323.

Petkovski, T.K., 1986. Zur Taxonomie des Genus Mesocyclops G.O. Sars 1914 (Crustacea, Copepoda Cyclopoida) in der Neotropis. Acta Mus. maced. Sci. nat., 18(3/149): 47-49.

Petkovski, T.K., 1988. Zur Cyclopidenfauna Kolumbiens
(Crustacea, Copepoda). Acta Mus. maced. Sci. nat., 19 (2/155): 39-64.

Reddell, J.R., 1965. A checklist of the cave fauna of Texas, I. The Invertebrata (exclusive of Insecta). Texas J. Sci., 17(2): 143-187.

Reddell, J.R., 1981. A review of the cavernicole fauna of Mexico, Guatemala, and Belize. Bull. Texas Meml. Mus., 27: 1-327.

Reddell, J.R. \& R.W. Mitchell, 1969. A checklist and annotated bibliography of the subterranean aquatic fauna of Texas. International Center for Arid and Semi-Arid Land Studies, Texas Technological College Water Resources Center, Lubbock, Texas, Spec. Rep., 24: 1-48.

Reid, J.W., 1985. Chave de identificação e lista de referências bibliográficas para as espécies continentais sulamericanas de vida livre da ordem Cyclopoida (Crustacea, Copepoda). Bolm. Zool., Univ. São Paulo, 9: 17-143.

Reid, J.W., 1988. Copepoda (Crustacea) from a seasonally flooded marsh in Rock Creek Stream Valley Park, Maryland. Proc. biol. Soc. Wash., 101(1): 31-38.

Reid, J.W., 1990. Continental and coastal free-living Copepoda (Crustacea) of Mexico, Central America and the Caribbean Region. In: D. Navarro L. \& J.G. Robinson (eds.), Diversidad Biologica en la Reserva de la Biosfera de Sian Ka'an, Quintana Roo, México: 175-213 (Centro de Investigaciones de Quintana Roo (CIQRO) \& Program of Studies in Tropical Conservation, University of Florida; Chetumal, Quintana Roo).

Reid, J.W., 1992. Copepoda (Crustacea) from fresh waters of the Florida Everglades, U.S.A., with a description of Eucyclops conrowae n. sp. Trans. amer. microsc. Soc., 111(3): 229-254.

Reid, J.W., S.G.F. Hare \& R.S. Nasci, 1989. Diacyclops navus (Crustacea: Copepoda) redescribed from Louisiana, U.S.A. Trans. amer. microsc. Soc., 108(4): 332-344.

Reid, J.W. \& B.H. Kay, 1992. Mesocyclops guangxiensis, new species, and new records of four congeners (Crustacea: Copepoda: Cyclopidae) from China, Laos, and Viet Nam. Proc. biol. Soc. Wash., 105(2): 331-342.

Reid, J.W., E.B. Reed, J.V. Ward, N.J. Voelz \& J.A. Stanford, 1991. Diacyclops languidoides (Lilljeborg, 1901) s. 1. and Acanthocyclops montana, new species (Copepoda, Cyclopoida), from groundwater in Montana, U.S.A. Hydrobiologia, 218(2): 133-149.

Sars, G.O., 1914. An account of the Crustacea of Norway with short descriptions and figures of all the species. VI. Copepoda Cyclopoida. Parts V and VI. Cyclopidae (continued): 57-80 (Bergen Museum, Bergen).

Schmankevitch, V.I., 1875. Quelques Crustacés des eaux salées et douces et leurs rapports avec l'élément environnant. Mém. Soc. Naturalistes nouvelle Russie, Odessa (= Zap. novoross. Obshch. Estest.), 3(2): 1-391, pls. 1-5.

Sket, B., 1988. Fauna of the hypogean waters of the San Andres (Saint Andrews) Island, Colombia. Biol. Vestn., 36(2): 7782.

Smith, K.E. \& C.H. Fernando, 1978. The freshwater calanoid 
and cyclopoid Crustacea of Cuba. Can. J. Zool., 56(9): 2015-2023.

Smith, K.E. \& C.H. Fernando, 1980. Guía para los copépodos (Calanoida y Cyclopoida) de Cuba: 1-28 (Academia de Ciencias de Cuba, Havana).

Tai, A.-y. \& G.-x. Chen, 1979. Cyclopoida. In: C.-j. Shen (ed.), Fauna Sinica: Crustacea: Freshwater Copepoda: 301-420 (Science Press, Peiping).

Velde, I. van de, 1984a. Revision of the African species of the genus Mesocyclops Sars, 1914 (Copepoda: Cyclopidae). Hydrobiologia, 109(1): 3-66.

Velde, I. van de, $1984 \mathrm{~b}$. Introduction of new identification characters in Mesocyclops, with African species as an example. Crustaceana, Suppl. 7(2): 404-419.

Velde, I. van de, 1987. New Mesocyclops species (Copepoda, Cyclopidae) from Papua New Guinea. Bull. Inst. roy. Sci. nat. Belg., (Biol.) 57: 149-162.

Yeatman, H.C., 1977. Mesocyclops ellipticus Kiefer from a Mexican cave. In: J.R. Reddell (ed.), Studies on the caves and cave fauna of the Yucatan Peninsula. Bull. Ass. mex. Cave Stud., 6: 5-7.

Received: 26 February 1993 